\title{
Research Paper Efficiency of chilli futures trading in terms of price discovery and price transmission
}

See end of the paper for authors' affiliations

Correspondence to :

\section{J. Naipunya}

Department of Agricultural

Economics, S.V. Agricultural

College, Acharya N.G Ranga

Agricultural University,

Tirupati (A.P.) India

Email: juturu.punya@gmail. com

Paper History :

Received : 24.06.2020;

Revised : 06.07.2020;

Accepted : 07.08.2020
ABSTRACT : This paper has examined the efficiency of futures trading of chilli in terms of price discovery and transmission. Seemingly unrelated regression" (SUR) model, Johansen's multiple cointegrationtest, granger causality test and vector error correction model was applied to draw the results. Chilli spot market (Guntur) was efficient in price discovery. The Silbers and Garbage value of futures market was 0.0403 being significant at 1 per cent level (0.0037) indicating that futures market of chilli was inefficient in price discovery. The findings of the ADF test suggested that futures and spot prices of chilli attained stationarity at first difference. The co-integration test revealed the presence of one co-integrating equation and confirmed the long-run equilibrium relationship among futures and spot prices of chilli and spot markets came to short-run equilibrium as indicated by level of significance at 5 per cent i.e. (0.022), any disturbances in price would get corrected within 3 hours in spot markets as indicated by co-efficient values.

KEY WORDS : ADF, Johansen's multiple co-integration test, Granger causality test, VECM

How To Cite This Paper : Naipunya, J., Devi, I. Bhavani and Rao, D. Vishnusankar (2020). Efficiency of chilli futures trading in terms of price discovery and price transmission. Internat. Res. J. Agric. Eco. \& Stat., 11 (2) : 137-143, DOI : 10.15740/HAS/IRJAES/11.2/137-143. Copyright@2020:Hind Agri-Horticultural Society. 